\title{
Effect of dietary forage to concentrate ratio on volatile fatty acid absorption and the expression of genes related to volatile fatty acid absorption and metabolism in ruminal tissue
}

\author{
G. B. Penner, ${ }^{*}$ M. Taniguchi, ${ }^{* 1}$ L. L. Guan, ${ }^{*}$ K. A. Beauchemin, $†$ and M. Oba ${ }^{* 2}$ \\ *Department of Agricultural, Food and Nutritional Science, University of Alberta, Edmonton, T6G 2P5, Canada \\ †Agriculture and Agri-Food Canada, Research Center, Lethbridge, AB, T1J 4B1, Canada
}

\begin{abstract}
The objective of the study was to investigate the fractional rate of volatile fatty acid (VFA) absorption and the expression of genes encoding for transporters and enzymes involved in the absorption and metabolism of VFA in ruminal tissue when cattle were fed high or low concentrate diets. Twelve ruminally cannulated Holstein cows were used in a randomized complete block design. The low concentrate (LC) and high concentrate (HC) diets contained 8 and $64 \%$ dietary concentrate (dry matter basis), respectively. Cows were fed their respective diet for at least $28 \mathrm{~d}$, following which data and samples were collected over $6 \mathrm{~d}$. Ruminal $\mathrm{pH}$ was measured continuously for $72 \mathrm{~h}$, and the in vivo VFA absorption and passage rates were measured using CoEDTA and n-valeric acid as markers. Ruminal tissue was collected postslaughter from the ventral sac of the rumen, and gene expression was evaluated using quantitative real-time PCR. Dry matter intake was not affected by treatment, averaging $14.9 \mathrm{~kg} / \mathrm{d}$, but cows fed $\mathrm{HC}$ had lower mean ruminal $\mathrm{pH}$ (6.03 vs. 6.48), and a greater duration (376 vs. $10 \mathrm{~min} / \mathrm{d}$ ) that ruminal $\mathrm{pH}$ was <5.8. Ruminal VFA concentration was $24 \mathrm{mM}$ higher for cows fed HC compared with LC; however, the fractional rate of VFA absorption and passage from the rumen was not affected by dietary treatment, averaging 23.4 and $9.6 \% / \mathrm{h}$, respectively. The expression of genes encoding for enzymes involved in VFA activation and ketogenesis were not affected by treatment. Cows fed $\mathrm{HC}$ tended to have a relative abundance of pyruvate dehydrogenase lipoamide $\alpha 1 \mathrm{mRNA}$ transcripts that was 1.4 times lower than that of cows fed LC, but other enzymes involved in pyruvate metabolism or
\end{abstract}

Received September 15, 2008

Accepted February 5, 2009.

${ }^{1}$ Present address: Animal Genome Research Unit, Division of Animal Sciences, National Institute of Agrobiological Sciences, 2 Ikenodai, Tsukuba, Ibaraki 305-8602, Japan.

${ }^{2}$ Corresponding author: masahito.oba@afhe.ualberta.ca regulation of the citric acid cycle were not affected. Collectively, these results suggest that the dietary forage to concentrate ratio does not affect the fractional rate of VFA absorption in vivo, but potentially alters energy metabolism in ruminal tissue.

Key words: forage-to-concentrate ratio, gene expression, ruminal $\mathrm{pH}$, volatile fatty acid absorption

\section{INTRODUCTION}

Ruminal acidosis is one of the most prominent digestive disorders in commercial dairy production with prevalence, diagnosed using rumenocentesis, ranging between 12 and 30\% throughout lactation (Krause and Oetzel, 2006). The majority of past research examining ruminal acidosis has focused on dietary factors including ration particle size distribution, diet fermentability, and microbial factors (Nagaraja and Titgemeyer, 2007; Enemark, 2008). In contrast, the absorption and clearance of acid from the rumen has received little attention. Allen (1997) calculated that approximately $53 \%$ of protons produced during anaerobic fermentation were removed from the rumen through the absorption of VFA across the ruminal wall implying that absorptive metabolism may have a strong effect on the regulation of ruminal $\mathrm{pH}$.

Past research has demonstrated that diet can affect the absorptive metabolism in ruminal tissue. Diets containing a higher proportion of concentrate have previously been shown to increase VFA disappearance from the rumen by absorption (Gäbel et al., 1991) and the net absorption rate in vitro (Uppal et al., 2003). Further, feeding high-concentrate diets increased the oxidation of acetate and butyrate in steers per unit of tissue (Harmon et al., 1991), and the activity of $\mathrm{Na}^{+} /$ $\mathrm{K}^{+}$ATPase per milligram of protein in lambs (McLeod and Baldwin, 2000) relative to those fed low-concentrate diets, suggesting that the regulation of VFA transport likely differs between animals fed diets predisposing them to low ruminal $\mathrm{pH}$ and a high ruminal VFA concentration. Gäbel and Aschenbach (2006) reviewed the 
literature and identified numerous regulatory factors involved in the absorption of VFA, including regulation of intracellular $\mathrm{pH}$ and catabolism of VFA. However, the majority of reviewed studies were conducted using sheep epithelia, justifying further investigation into regulatory mechanisms in cattle.

We hypothesized that feeding more concentrate would increase the fractional rate of VFA absorption in vivo, and would up-regulate the relative expression of genes involved in the regulation of VFA absorption and metabolism. As such, the objective of this study was to investigate the fractional rate of VFA absorption in vivo, and the expression of genes encoding for transporters and enzymes involved in VFA absorption and energy metabolism in ruminal tissue when cattle were fed high- or low-concentrate diets.

\section{MATERIALS AND METHODS}

Animals used in this study were cared for in accordance with the guidelines of the Canadian Council on Animal Care (Ottawa, Ontario, Canada). All procedures were preapproved by the Lethbridge Research Centre Animal Care Committee.

\section{Animals and Dietary Treatments}

Twelve nonpregnant, nonlactating, ruminally cannulated Holstein cows from the Lethbridge Research Centre were used for this study. Cows were housed in tie-stalls bedded with wood shavings and were allowed to exercise daily. Cows were randomly assigned to 1 of 2 dietary treatments after being blocked by age and BW. The treatments contained concentrate at 8 (low concentrate, LC) and 64\% (high concentrate, HC) of dietary DM (Table 1), respectively. Diets were formulated using the Cornell-Penn-Miner Dairy system (CPM Dairy, Version 3.0.8.01; Cornell University, Ithaca, NY; University of Pennsylvania, Kennett Square, PA; and William H. Miner Agricultural Research Institute, Chazy, NY) to supply adequate MP and ME for a dry cow weighing $650 \mathrm{~kg}$. The nutrient composition of the $\mathrm{HC}$ and $\mathrm{LC}$ diets is presented in Table 1. Increasing the proportion of barley grain in replacement for barley silage numerically increased the dietary DM from 48.5 to $67.8 \%$, and decreased dietary NDF by nearly $16 \%$. The concentration of $\mathrm{CP}$ was similar across treatments, averaging $12.7 \%$. The $\mathrm{LC}$ and $\mathrm{HC}$ diets had forage to concentrate ratios of 92:8 and 36:64, respectively. Adaptation to the $\mathrm{HC}$ diet was carried out over $10 \mathrm{~d}$, and cows received their respective treatment for at least 28 $\mathrm{d}$ before slaughter. Cows were fed for ad libitum intake in 2 equal portions at 0800 and $1300 \mathrm{~h}$ daily, and had free access to water.
Table 1. Ingredient and nutrient composition of the low (LC) and high concentrate $(\mathrm{HC})$ diets

\begin{tabular}{lcc}
\hline & \multicolumn{2}{c}{ Treatment } \\
\cline { 2 - 3 } Item & LC & $\mathrm{HC}$ \\
\hline Ingredient, \% of DM & & \\
Alfalfa hay & 14.5 & 5.7 \\
Rolled barley grain & 4.1 & 44.3 \\
Barley silage & 77.2 & 30.1 \\
Ground barley grain & 2.0 & 16.9 \\
Canola meal & 1.2 & 1.3 \\
Mineral and vitamin mix & 1.0 & 1.7 \\
Canola oil & 0.02 & 0.09 \\
Nutrient composition & 48.5 & 67.8 \\
DM & 9.8 & 6.7 \\
Ash, \% of DM & 12.5 & 12.9 \\
CP, \% of DM & 44.2 & 28.3 \\
NDF, \% of DM & 97.0 & 59.0 \\
Forage NDF, \% of NDF & 42.9 & 16.7 \\
Forage NDF, \% of DM & 91.7 & 35.8 \\
Forage, \% &
\end{tabular}

${ }^{1}$ Contained $36.3 \% \mathrm{Na}, 55.7 \% \mathrm{Cl}, 9,151 \mathrm{mg} / \mathrm{kg}$ of $\mathrm{Zn}, 2,294 \mathrm{mg} / \mathrm{kg}$ of $\mathrm{Cu}, 3,545 \mathrm{mg} / \mathrm{kg}$ of $\mathrm{Mn}, 33.1 \mathrm{mg} / \mathrm{kg}$ of Co, $82.4 \mathrm{mg} / \mathrm{kg}$ of I, $761.1 \mathrm{kIU}$ vitamin $\mathrm{A}, 190.3 \mathrm{kIU}$ vitamin $\mathrm{D}$, and 4,507.0 $\mathrm{kIU}$ vitamin $\mathrm{E}$.

\section{Experimental Measurements and Procedures}

Each pair of cows was subjected to a 5 -d collection period following a 28-d adaptation period. Collection periods were staggered for each pair. Body weight and BCS (5-point system; Wildman et al., 1982) were measured on the first day of collection. The amounts of feed offered and refused were measured daily during the entire collection period, and samples of the feed refusals were composited over the collection period and dried for $\mathrm{DM}$ determination at $55^{\circ} \mathrm{C}$. Feed ingredients were collected daily and composited by week. Dried dietary ingredients were ground to pass through a $1-\mathrm{mm}$ screen using a Wiley mill (Thomas-Wiley, Philadelphia, PA), and analyzed for concentrations of DM, ash, CP, and NDF. Dry matter concentration was determined after drying samples at $135^{\circ} \mathrm{C}$ for $2 \mathrm{~h}$ (AOAC, 1990; method 930.15), and the ash concentration was determined after placing the samples in a muffle furnace for $5 \mathrm{~h}$ at $550^{\circ} \mathrm{C}$ (AOAC 1990; method 942.05). Crude protein concentration was quantified by flash combustion with gas chromatography and thermal conductivity detection (Carlo Erba Instruments, Milan, Italy; Rhee, 2005). Concentration of NDF was determined using amylase and sodium sulfite (Van Soest et al., 1991).

Ruminal $\boldsymbol{p H}$ Measurement. Ruminal $\mathrm{pH}$ was measured every $30 \mathrm{~s}$, and data were averaged over 1-min intervals for the first $72 \mathrm{~h}$ of each collection period using the Lethbridge Research Centre Ruminal pH Measurement System (Dascor, Escondido, CA) as described previously by Penner et al. (2006a). Daily minimum, mean, and maximum $\mathrm{pH}$ values were averaged for each 
cow. The occurrence and extent of ruminal $\mathrm{pH}$ depression was summarized as the number of episodes, duration, and area below the $\mathrm{pH}$ threshold of 5.8 (Penner et al., 2007). An acidosis index was calculated by dividing the area that ruminal $\mathrm{pH}$ was $<5.8$ by DMI to evaluate the severity of ruminal acidosis normalized for DMI. The use of acidosis index allows us to evaluate whether the severity of ruminal acidosis is related to differences in absorptive metabolism of VFA by removing confounding effects of DMI on ruminal $\mathrm{pH}$.

Ruminal Fluid and Blood Collection and Analysis. Ruminal fluid and blood were collected every $9 \mathrm{~h}$ over a 72-h duration starting on $\mathrm{d} 1$ of each collection period to account for diurnal variation. Subsamples of ruminal fluid were collected in equal proportions from the cranial dorsal, cranial ventral, central rumen, caudal dorsal, and caudal ventral regions $(250 \mathrm{~mL}$ from each region), and combined to form one sample. $\mathrm{Ru}-$ minal fluid was strained through a perforated material (Peetex, pore size $=355 \mu \mathrm{m}$; Sefar Canada Inc., Scarborough, Canada), and the 10-mL sample was added to $2 \mathrm{~mL}$ of $25 \%$ metaphosphoric acid. Samples were stored at $-20^{\circ} \mathrm{C}$, and a composite sample for each cow was used for analysis.

Ruminal VFA were separated and quantified by gas chromatography. Samples were injected by an auto sampler (model 8200, Varian, Walnut Creek, CA) into a Stabilwax-DA column $(30 \mathrm{~m} \times 0.53 \mathrm{~mm}$ i.d. $\times 0.5$ $\mu \mathrm{m}$ film) on a Varian GC (model 3400, Varian). The samples were run at a split ratio of $20: 1$ with a column temperature of 90 to $170^{\circ} \mathrm{C}$ with an increase of $10^{\circ} \mathrm{C} /$ min followed by a 2-min hold. The injector and detector temperatures were 170 and $190^{\circ} \mathrm{C}$, respectively. Peak integration was performed using Galaxie Software (Varian). All ruminal fluid samples were assayed in duplicate. Ruminal $\mathrm{NH}_{3}-\mathrm{N}$ concentration was determined colorimetrically as described by Fawcett and Scott (1960).

Blood was collected from the coccygeal vessel into evacuated tubes containing Na-heparin (Fisher Scientific Company, Nepean, Ontario, Canada). Plasma was harvested by centrifuging the blood samples at 3,000 $\times g$ at $4^{\circ} \mathrm{C}$ for 25 min immediately after collection. A composite sample of plasma was prepared from the 8 individual sampling times, and all samples were stored at $-20^{\circ} \mathrm{C}$ until analysis.

Plasma samples were analyzed for glucose, insulin, BHBA, and plasma urea nitrogen (PUN) concentrations. Plasma glucose concentration was measured using a glucose oxidase/peroxidase enzyme (P7119, Sigma, St. Louis, MO) and dianisidine dihydrochloride (F5803, Sigma). Absorbance was determined with a plate reader (SpectraMax 190, Molecular Devices Corp., Sunnyvale, CA). A commercial kit was used to determine the plasma concentration of insulin (Coat-A-Count, Diagnostic Products Corporation, Los Angeles, CA). Plasma BHBA concentration was determined using the enzymatic oxidation of BHBA to acetoacetate using 3-hydroxybutrate dehydrogenase (No. H6501; Roche, Mississauga, ON, Canada), and the concomitant reduction of NAD to NADH was determined using a plate reader at a wavelength of $340 \mathrm{~nm}$. The concentration of PUN was determined according to Fawcett and Scott (1960), but modified to include urease at the beginning of the procedure.

Ruminal VFA Clearance and Volume. Ruminal VFA clearance rate was estimated on d 4 of each collection period using Co-EDTA (Uden et al., 1980) as a fluid passage marker, and n-valeric acid as an indicator of VFA clearance from the rumen (Allen et al., 2000; Resende Júnior et al., 2006). The n-valeric acid was used as a marker for VFA absorption, as Resende Júnior et al. (2006) found that the fractional rate of VFA absorption and passage obtained using the Co-EDTA and nvaleric acid method did not differ from results obtained using individual VFA labeled with ${ }^{13} \mathrm{C}$. To minimize fluctuations in baseline valeric acid concentration, cows were provided their feed in 3 equal proportions at 1300, 2100 , and $0500 \mathrm{~h}$ starting the day before the marker dose. Each cow received a 2.5-L solution containing $300 \mathrm{~g}$ of n-valeric acid (VWR International, Edmonton, $\mathrm{AB}$, Canada), and $125 \mathrm{~g}$ of Co-EDTA buffered to $\mathrm{pH}$ 6.2 with $\mathrm{NaOH}$. The Co-EDTA/n-valeric acid solution was thoroughly mixed by hand into the ruminal contents. An initial sample was collected immediately before the marker dose (time 0), and subsequent ruminal fluid samples were collected at 30,60, 120, 180, 360, $720,1,080$, and 1,440 min after the dose. Individual samples of ruminal fluid were analyzed for valeric acid concentration as described previously, and for Co concentration using atomic absorption (AA240FS, Varian, Palo Alto, CA).

Baseline concentrations (time 0) of Co and n-valeric acid were used to correct concentrations measured at each individual time point (i.e., 30, 60, 120, 180, 360, $720,1,080$, and 1,440 min relative to dosing). The exponential rate of decay for Co and n-valeric acid were calculated as described by Resende Júnior et al. (2006) using the PROC NLIN procedure of SAS (version 9.1, SAS Institute Inc., Cary, NC) using the equation $R_{t}$ $=\mathrm{R}_{0} \times \mathrm{e}^{-\mathrm{k} \times \mathrm{t}}$, where $\mathrm{R}_{\mathrm{t}}=$ concentration at a given time, $\mathrm{R}_{0}=$ concentration at time $0, \mathrm{k}=$ fractional rate of clearance, $\mathrm{t}=$ time, $\mathrm{h}$. To calculate the fractional rate of VFA absorption, the rate of Co clearance was subtracted from the rate of n-valeric acid clearance.

Ruminal content volume was determined by completely evacuating the rumen 1,500 min after the marker dose. The ruminal digesta was thoroughly mixed and 
duplicate samples were taken to determine ruminal content of $\mathrm{DM}\left(55^{\circ} \mathrm{C}\right)$ and the solid and liquid pool sizes.

Cow Transportation and Slaughter. One to two days following the collection period, cows were transported to a licensed abattoir, and killed by captive bolt stunning and exsanguination. Whole ruminal tissue samples including the mucosal and submucosal layers were collected from the ventral sac, rinsed in $90 \%$ saline, and snap-frozen in liquid nitrogen. Tissues were stored at $-80^{\circ} \mathrm{C}$ until further analysis.

Extraction of RNA and Reverse Transcription. Total RNA was extracted from ground ruminal tissue using Trizol (Invitrogen, Burlington, ON, Canada) as described by Chomczynski and Sacchi (1987). The RNA concentration was determined by measuring the absorbance at 260 and $280 \mathrm{~nm}$ using NanoDrop (ND-1000, NanoDrop Technologies, Wilmington, DE). All samples had an absorbance ratio (260:280) between 1.91 and 2.29, indicating high RNA purity. Samples were then diluted to contain $100 \mathrm{ng}$ of $\mathrm{RNA} / \mu \mathrm{L}$. All RNA samples were treated with DNase I (Invitrogen) to remove potential genomic DNA contamination. The Superscript II kit (Invitrogen) was used to synthesize single strand cDNA.

Quantitative Real-Time PCR. Primers and Taqman probes used in this study were designed by Primer Express software (Applied Biosystems, Foster City, CA), and it was confirmed that they included the intron/exon boundary. The target genes of interest and their respective GenBank accession number and primer sequences are listed in Table 2. Quantitative real-time PCR (qRT-PCR) was conducted using a 7900HT Fast Real-Time PCR System (Applied BioSystems) with a 10 -min preincubation at $95^{\circ} \mathrm{C}$ followed by 40 cycles composed of $15 \mathrm{~s}$ at $95^{\circ} \mathrm{C}$ and $60 \mathrm{~s}$ at $60^{\circ} \mathrm{C}$. All samples were analyzed in triplicate.

The point at which the florescent signal of the PCR product crossed the threshold was deemed to be the threshold crossing value $\left(\mathbf{C}_{\mathbf{T}}\right)$. The average $\mathrm{C}_{\mathrm{T}}$ for each cow and gene was compared with each cow's respective average $\mathrm{C}_{\mathrm{T}}$ for the housekeeping gene ribosomal protein large P0 (RPLP0) by subtracting $\mathrm{C}_{\mathrm{T}}$ of RPLP0 from the $\mathrm{C}_{\mathrm{T}}$ of the target gene to calculate $\Delta \mathrm{C}_{\mathrm{T}}$. To compare the expression of genes between treatments, the cow with the lowest acidosis index $(\mathrm{pH}<5.8 \times \mathrm{min} / \mathrm{d} \div$ DMI, $\mathrm{kg} / \mathrm{d}$ ) was used as the calibrator. The cow with the lowest acidosis index was on the $\mathrm{LC}$ treatment and had an acidosis index value of 0.00 . The $\Delta \mathrm{C}_{\mathrm{T}}$ of this cow was then used as a reference value to calculate $\Delta \Delta \mathrm{C}_{\mathrm{T}}$, which yielded a $\Delta \Delta \mathrm{C}_{\mathrm{T}}$ value of 0 for the cow used as the calibrator. Furthermore, the fold change in gene expression was calculated as $2^{-\Delta \Delta C} \mathrm{~T}$ (Livak and Schmittgen, 2001; Ontsouka et al., 2004).

\section{Statistical Analysis}

Data were analyzed as a randomized complete block design using the PROC MIXED procedure of SAS (version 9.1, SAS Institute Inc., Cary, NC) with the fixed effects of block ( 6 blocks were used to pair cows balanced for age and BW) and treatment. Significance was declared when $P<0.05$ and trends are discussed when $P<0.10$.

\section{RESULTS}

\section{DMI, Ruminal Fermentation, Ruminal Volume, and VFA Absorption}

Dietary treatment did not affect DMI (Table 3), but a large variation was observed in both treatments. For example, DMI ranged from 10.6 to $20.2 \mathrm{~kg} / \mathrm{d}$ and from 11.3 to $20.4 \mathrm{~kg} / \mathrm{d}$ for the $\mathrm{HC}$ and $\mathrm{LC}$ treatments, respectively. Body weight and BCS were not affected by treatment with mean values of $816 \mathrm{~kg}$ and 3.85 BCS across treatments, respectively.

Cows fed HC had greater total VFA concentration in ruminal fluid than cows fed LC (138 vs. $114 \mathrm{mM} P<<$ $0.01)$. Furthermore, feeding $\mathrm{HC}$ decreased $(P<0.01)$ the molar proportion of acetate by $20 \%$, and increased $(P<0.05)$ the molar proportions of propionate, butyrate, valerate, and isovalerate by $28,32,39$, and $53 \%$ respectively. The acetate to propionate ratio was lower $(P<0.01)$ for cows fed the HC treatment than cows fed the LC treatment (2.36 vs. 3.98 ).

Minimum and mean $\mathrm{pH}$ were nearly 0.6 and $0.5 \mathrm{pH}$ units lower $(P<0.01)$, respectively, for cows fed HC than those fed LC. Maximum $\mathrm{pH}$ was not different between treatments. Feeding the HC diet effectively increased the severity of ruminal acidosis as indicated by increased episodes ( 13.5 vs. $0.3 / \mathrm{d} ; P<0.01)$, duration $(376$ vs. $10 \mathrm{~min} / \mathrm{d} ; P<0.01)$, and area (88.7 vs. $0.8 \mathrm{pH}$ $\times \min / \mathrm{d} ; P<0.01)$ that $\mathrm{pH}$ was below 5.8 .

\section{Ruminal Volume and VFA Absorption}

Ruminal digesta weight and DM concentration were not different between treatments, averaging $87.5 \mathrm{~kg}$ and $13.5 \%$, respectively (Table 4 ). Dietary treatment did not affect the fractional rate of VFA absorption or passage from the rumen, averaging 23.4 and $9.6 \% / \mathrm{h}$, respectively. In addition, diet did not affect the estimated rates of total VFA or acetate absorption, which averaged 2.22 and $1.16 \mathrm{~mol} / \mathrm{h}$, respectively. However, the estimated rates of propionate and butyrate absorption were 0.23 and $0.14 \mathrm{~mol} / \mathrm{h}$ greater $(P<0.05)$ for cows fed HC compared with those fed LC, respectively. The estimated passage rate of VFA $(\mathrm{mol} / \mathrm{h})$ was not different between treatments. 
Table 2. Gene name, National Center for Biotechnology Information (NCBI) accession number, and primer and probe sequences for quantitative real-time PCR analysis

\begin{tabular}{|c|c|c|c|}
\hline Gene name (abbreviation) & Accession number & Primer and probe sequences & Functional pathway \\
\hline Ribosomal protein, large, P0 (RPLP0) & NM_001012682 & $\begin{array}{l}\text { Forward: AGGGCGTCCGCAATGTT } \\
\text { Reverse: CGACGGTTGGGTAACCAATC } \\
\text { Probe: CCAGCGTGTGCCTG }\end{array}$ & Endogenous control \\
\hline $\begin{array}{l}\text { Acyl-CoA synthetase short-chain family } \\
\text { member } 1 \text { (acyl-CoA synthetase) }\end{array}$ & BC114698.1 & $\begin{array}{l}\text { Forward: CCGATCAGGTCCTGGTAGTGA } \\
\text { Reverse: GCCTCCGCATGACTTTTCC } \\
\text { Probe: CGTCTTCCAAAAACT }\end{array}$ & VFA activation \\
\hline Acetyl-CoA synthetase 2 (acetyl-CoA synthetase) & DQ489534 & $\begin{array}{l}\text { Forward: GCTCTCACTGAGGAGCTCAAGAA } \\
\text { Reverse: AATCCGGTGTGGCAATGG } \\
\text { Probe: AGATTAGAGAAAAGATTGGC }\end{array}$ & VFA activation \\
\hline $\begin{array}{l}\text { Acyl-CoA synthetase medium-chain family } \\
\text { member } 1 \text { (butyrl-CoA synthetase) }\end{array}$ & BC109602 & $\begin{array}{l}\text { Forward: ACCCTTTGACATTCAGATCATTGAT } \\
\text { Reverse: CCAATGTTTCCTTCCGTGTTG } \\
\text { Probe: CAAGGGCAATATCCAGC }\end{array}$ & VFA activation \\
\hline $\begin{array}{l}\text { Solute carrier family } 25 \text {, carnitine/acylcarnitine } \\
\text { translocase, member } 20 \text { (acyl-carnitine) }\end{array}$ & NM_001077936 & $\begin{array}{l}\text { Forward: CTCAAGTCCCGCTTCCAGACT } \\
\text { Reverse: CCTCAGCACATCTTTGAAACCA } \\
\text { Probe: CTCCTGGGAAATATCCTA }\end{array}$ & Fatty acid transport \\
\hline Acetyl-CoA acyltransferase 1 (acetyl-CoA acyltransferase) & BC102927 & $\begin{array}{l}\text { Forward: CACTGGCTTCCCAGCAAAA } \\
\text { Reverse: ACGATCTCGGCCTGGAAAC } \\
\text { Probe: AGCCAGAGCCCAGAGA }\end{array}$ & Ketogenesis \\
\hline 3-Hydroxy-3-methylglutaryl-CoA synthase 1 (HMGS) & AY581197 & $\begin{array}{l}\text { Forward: AGGATACTCATCACTTGGCCAACT } \\
\text { Reverse: CATGTTCCTTCGAAGAGGGAAT } \\
\text { Probe: CATTCCCCAGAGTTCCA }\end{array}$ & Ketogenesis \\
\hline $\begin{array}{l}\text { 3-Hydroxymethyl-3-methylglutaryl-CoA lyase, } \\
\text { hydroxymethylglutaricaciduria (HMGL) }\end{array}$ & NM_001075132 & $\begin{array}{l}\text { Forward: TGCAGATGGGAGTGAGTGTCA } \\
\text { Reverse: GACGCCCCCTGTGCATAG } \\
\text { Probe: TGGCAGGACTGGGAG }\end{array}$ & Ketogenesis \\
\hline 3-Hydroxybutyrate dehydrogenase, type 1 (BDH1) & NM_001034600 & $\begin{array}{l}\text { Forward: GACTGCCACCACTCCCTACAC } \\
\text { Reverse: TCCGCAGCCACCAGTAGTAGT } \\
\text { Probe: CGCTACCATCCCATG }\end{array}$ & Ketogenesis \\
\hline 3-Hydroxybutyrate dehydrogenase, type 2 (BDH2) & NM_001034488 & $\begin{array}{l}\text { Forward: CTGTGGCTTCCAGCATCAAA } \\
\text { Reverse: CGCCTTGGTTGTGCTGTACA } \\
\text { Probe: CGTTGTGAACAGGTGC }\end{array}$ & Ketogenesis \\
\hline $\begin{array}{l}\text { Propionyl coenzyme A carboxylase, } \alpha \\
\text { polypeptide (propionyl-CoA carboxylase) }\end{array}$ & BC123876 & $\begin{array}{l}\text { Forward: AGAATGGAAGATGCCCTGGAT } \\
\text { Reverse: CCTCTCGAAGCAATGCGATAT } \\
\text { Probe: TTATGTTATTCGAGGTGTTACAC }\end{array}$ & Propionate metabolism \\
\hline Lactate dehydrogenase isoform A (LDHa) & BC146210 & $\begin{array}{l}\text { Forward: GGCAAAGACTATAATGTGACAGCAA } \\
\text { Reverse: ACGTGCCCCAGCTGTGA } \\
\text { Probe: CTCCAGGCTGGTTATT }\end{array}$ & Pyruvate metabolism \\
\hline Lactate dehydrogenase isoform $\mathrm{B}$ ( $\mathrm{LDHb})$ & BC142006 & $\begin{array}{l}\text { Forward: CCAACCCAGTGGATATTCTCACA } \\
\text { Reverse: TCACACGGTGCTTGGGTAATC } \\
\text { Probe: TGTTACCTGGAAACTAAG }\end{array}$ & Pyruvate metabolism \\
\hline Pyruvate carboxylase (PC) & NM_177946 & $\begin{array}{l}\text { Forward: CTCCCACCATCTGTCCTTTCC } \\
\text { Reverse: TTTATTTGGCAGGAGATGAATACG }\end{array}$ & Pyruvate metabolism \\
\hline
\end{tabular}

Pyruvate dehydrogenase, lipoamide, $\alpha 1$ (PDHA1)

NM_001101046 Forward: CAGTTTGCTACTGCTGATCCTGAA

Forward: CAGTTTGCTACTGCTGATCCTGAA Pyruvate metabolism

Isocitrate dehydrogenase $1, \mathrm{NADP}+$, soluble (IDH)

BC103368

Probe: ACCTTTGGAAGAACTCGGCTA

Forward: CTGGACCTGCACAGCTACGAT

Reverse: TGGTGACCTGGTCGTTGGT

Probe: TAGGCATAGAGAATCGCGA 


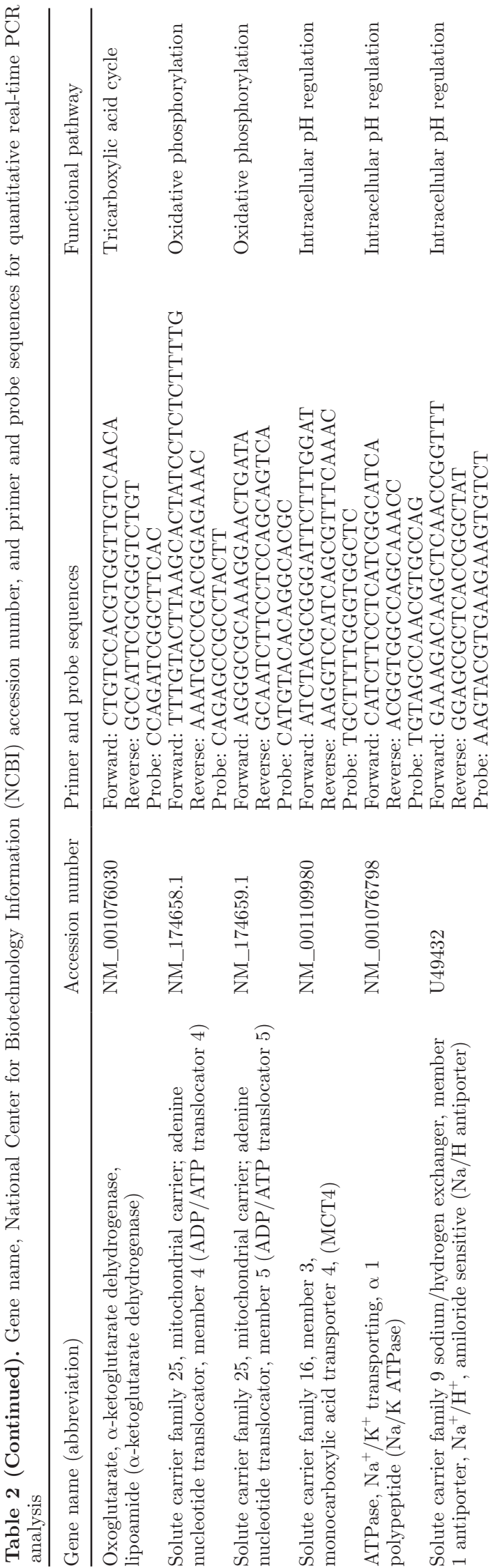

\section{Plasma Hormones and Metabolites}

Plasma glucose concentration was not affected by dietary treatment, averaging $64.3 \mathrm{mg} / \mathrm{dL}$, but plasma insulin concentration was 3 times higher for cows fed HC compared with LC ( $P=0.02$; Table 5$)$. In addition, cows fed the HC treatment had higher plasma BHBA concentration than cows fed the LC treatment (13.5 vs. $12.2 \mathrm{mg} / \mathrm{dL} ; P=0.05)$. The concentration of PUN was not affected by dietary treatment.

\section{Gene Expression}

The majority of the genes evaluated in ruminal tissue were not affected by dietary treatment (Table 6). Gene expression for 3 enzymes involved in the activation of VFA before metabolism, namely acyl-CoA synthetase short-chain family member 1 (acyl-CoA synthetase), acetyl-CoA synthetase 2 (acetyl-CoA synthetase), and acyl-CoA synthetase medium-chain family member 1 (butyrl-CoA synthetase) were not affected by treatment. Further, the gene expression for the solute carrier family 25, carnitine/acylcarnitine translocase, member 20 (acyl-carnitine) was not affected by dietary treatment. We selected 5 genes to evaluate in the pathway of ketogenesis including acetyl-CoA acyltransferase 1 (acetyl-CoA acyltransferase), 3-hydroxy-3-methylglutaryl-CoA synthase 1 (HMGS), 3-hydroxymethyl-3methylglutaryl-CoA lyase hydroxymethylglutaricaciduria (HMGL), and 2 isoforms of 3-hydroxybutyrate dehydrogenase: 3-hydroxybutyrate dehydrogenase, type 1 (BDH1) and type 2 (BDH2). There was no effect of feeding $\mathrm{HC}$ on the expression of any of the genes evaluated for the ketogenesis pathway.

Pyruvate is a key intermediate that can enter numerous pathways. As such, we evaluated the expression of genes coding for pyruvate carboxylase (PC), pyruvate dehydrogenase lipoamide $\alpha 1$ (PDHA1), and 2 isoforms of lactate dehydrogenase (LDHa and LDHb). Although the expression of PC and both isoforms of $\mathrm{LDH}$ was not affected by dietary treatment, cows fed $\mathrm{HC}$ tended to have lower expression (0.53 vs. $0.76 ; P=0.06)$ of PDHA1 than cows fed LC. Isocitrate dehydrogenase $1 \mathrm{NADP}^{+}$soluble (IDH) and oxoglutarate $\alpha$-ketoglutarate dehydrogenase lipoamide ( $\alpha$-ketogluturate dehydrogenase) are 2 rate-limiting enzymes in the citric acid cycle; however, dietary treatment did not affect the expression of genes encoding for either enzyme. In addition, we evaluated the expression of genes encoding for 3 transporters involved in intracellular $\mathrm{pH}$ regulation, and found that dietary treatment did not affect the expression of ATPase $\mathrm{Na}^{+} / \mathrm{K}^{+}$ transporting $\alpha 1$ polypeptide ( $\mathbf{N a} / \mathbf{K}$ ATPase), solute carrier family 9 sodium/hydrogen exchanger member 
Table 3. The effect of feeding low (LC) or high concentrate (HC) diet on DMI and rumen fermentation

\begin{tabular}{lcccc}
\hline & \multicolumn{2}{c}{ Treatment } & & \\
\cline { 2 - 3 } Variable & LC & HC & SEM & $P$-value \\
\hline DMI, kg/d & 14.0 & 15.8 & 1.4 & 0.387 \\
BW, kg & 813 & 820 & 46 & 0.914 \\
BCS & 3.83 & 3.88 & 0.24 & 0.904 \\
Rumen VFA & & & & \\
Total VFA, mM & 113.7 & 138.0 & 4.8 & 0.005 \\
Acetate, \% & 68.6 & 54.8 & 1.4 & $<0.001$ \\
Propionate, $\%$ & 17.4 & 24.2 & 1.4 & 0.006 \\
Butyrate, \% & 10.3 & 15.2 & 1.1 & 0.009 \\
Isobutyrate, $\%$ & 1.0 & 0.9 & 0.0 & 0.155 \\
Valerate, \% & 1.2 & 1.9 & 0.2 & 0.025 \\
Isovalerate, \% & 1.2 & 2.5 & 0.4 & 0.030 \\
Caproate, \% & 0.4 & 0.5 & 0.2 & 0.797 \\
Acetate:propionate & 3.98 & 2.36 & 0.22 & $<0.001$ \\
Rumen pH & & & & $<0.001$ \\
Minimum & 5.90 & 5.31 & 0.06 & $<0.001$ \\
Mean & 6.48 & 6.03 & 0.04 & 0.110 \\
Maximum & 6.85 & 6.72 & 0.05 & 0.002 \\
Standard deviation & 0.20 & 0.34 & 0.02 & $<0.001$ \\
Ruminal pH <5.8 & & & & $<0.001$ \\
Episodes, n/d & 0.3 & 13.5 & 1.1 & $<0.001$ \\
Duration, min/d & 10 & 376 & 43 & \\
Area, pH $\times$ min/d & 0.8 & 88.7 & 12.9 & \\
\hline$\quad$ & & & \\
\hline
\end{tabular}

1 antiporter $\mathrm{Na}^{+} / \mathrm{H}^{+}$amiloride sensitive $(\mathrm{Na} / \mathrm{H}$ antiporter), and solute carrier family 16 member 3 monocarboxylic acid transporter 4 (MCT4).

\section{Observed Variation Within the HC Treatment}

There was substantial variation detected among the 6 animals fed the $\mathrm{HC}$ diet for many response variables (data not shown). Daily minimum, mean, and maximum $\mathrm{pH}$ ranged from 5.1 to $5.6,5.9$ to 6.2 , and 6.5 to 6.9 , respectively. The duration that ruminal $\mathrm{pH}$ was below 5.8 ranged between 127 and $557 \mathrm{~min} / \mathrm{d}$ with an average value of $376 \mathrm{~min} / \mathrm{d}$. Similarly, the area that ruminal $\mathrm{pH}$ was below 5.8 ranged from 14.9 to $154 \mathrm{pH}$ $\times \mathrm{min} / \mathrm{d}$. The SEM for the area that ruminal $\mathrm{pH}$ was below 5.8 was greater than the area for the cow with the lowest value (18.2 vs. $14.9 \mathrm{pH} \times \mathrm{min} / \mathrm{d}$ respectively), indicating substantial variation. The acidosis index was calculated to normalize the response in ruminal $\mathrm{pH}$ for DMI and ranged between 6.4 and $17.2 \mathrm{pH} \times \mathrm{min} / \mathrm{kg}$ of DMI with a mean of $11.9 \mathrm{pH} \times \mathrm{min} / \mathrm{kg}$ of DMI.

Among cows fed the $\mathrm{HC}$ diet, no significant relationships were detected between the rate $(\% / \mathrm{h}$ and $\mathrm{mol} / \mathrm{h})$ of in vivo VFA absorption and the expression of genes related to VFA absorption and metabolism in ruminal tissue (data not shown). However, PDHA1 tended to be negatively correlated to the fractional rate of VFA absorption $(P=0.09, \mathrm{r}=-0.75$; data not shown).

Furthermore, among cows fed the HC diet, the acidosis index was negatively or tended to be negatively related to the expression of genes involved in the acti- vation of butyrate and enzymes in the pathway of ketogenesis, namely butyrl-CoA synthetase and HMGL $(P$ $=0.01$ and 0.08 , respectively; Figure 1). In both cases, one cow was detected as an outlier (DFFITS coefficient $>1.26$ ), and therefore the data are presented with and without the outlier. In the case of HMGL, removal of the outlier improved the correlation and resulted in a significant relationship. Furthermore, the expression of $\mathrm{LDHb}$ and $\mathrm{PC}$ were negatively related to the acidosis index $(P=0.03$ and 0.02 , respectively; Figure 2$)$, but the negative relationships for these genes were not observed when the outlier was removed from the data set. The gene expression for MCT4 tended $(P=0.07)$ to be positively related to the acidosis index $(\mathrm{r}=0.77$; data not shown).

\section{DISCUSSION}

\section{VFA Absorption}

The treatments used in this study successfully induced large differences in ruminal fermentation as indicated by differences in the total VFA concentration, molar proportions of individual VFA, and ruminal $\mathrm{pH}$ variables including mean $\mathrm{pH}$, and the duration and area that $\mathrm{pH}$ was $<5.8$. In fact, cows on the LC treatment experienced a depression in ruminal $\mathrm{pH}<5.8$ for only $10 \mathrm{~min} / \mathrm{d}$, whereas cows on the $\mathrm{HC}$ treatment had ruminal $\mathrm{pH}<5.8$ for nearly $6.5 \mathrm{~h} / \mathrm{d}$. These data indicate that cows fed the $\mathrm{HC}$ diet experienced ruminal acidosis as defined by Penner et al. (2007) although no clinical 
Table 4. The effect of feeding low (LC) or high concentrate (HC) diet on rumen volume and VFA absorption and passage

\begin{tabular}{|c|c|c|c|c|}
\hline \multirow[b]{2}{*}{ Variable } & \multicolumn{2}{|c|}{ Treatment } & \multirow[b]{2}{*}{ SEM } & \multirow[b]{2}{*}{$P$-value } \\
\hline & $\mathrm{LC}$ & $\mathrm{HC}$ & & \\
\hline \multicolumn{5}{|l|}{ Rumen volume } \\
\hline Rumen contents, kg & 90.0 & 85.0 & 5.5 & 0.530 \\
\hline Rumen DM, \% & 13.3 & 13.7 & 0.6 & 0.593 \\
\hline Rumen DM, kg & 11.9 & 11.6 & 0.7 & 0.831 \\
\hline Liquid fraction, $\mathrm{kg}$ & 78.2 & 73.4 & 5.0 & 0.513 \\
\hline \multicolumn{5}{|l|}{ VFA absorption and passage } \\
\hline Total VFA absorption, ${ }^{1} \% / \mathrm{h}$ & 22.7 & 24.2 & 1.9 & 0.591 \\
\hline Total VFA passage, ${ }^{2} \% / \mathrm{h}$ & 9.6 & 9.7 & 1.0 & 0.944 \\
\hline Total VFA absorption, ${ }^{3} \mathrm{~mol} / \mathrm{h}$ & 1.97 & 2.47 & 0.23 & 0.190 \\
\hline Acetate, ${ }^{4} \mathrm{~mol} / \mathrm{h}$ & 1.18 & 1.15 & 0.13 & 0.880 \\
\hline Propionate ${ }^{5} \mathrm{~mol} / \mathrm{h}$ & 0.35 & 0.58 & 0.06 & 0.046 \\
\hline Butyrate,${ }^{6} \mathrm{~mol} / \mathrm{h}$ & 0.18 & 0.32 & 0.03 & 0.024 \\
\hline Passage, ${ }^{7} \mathrm{~mol} / \mathrm{h}$ & 0.83 & 1.00 & 0.09 & 0.228 \\
\hline \multicolumn{5}{|c|}{$\begin{array}{l}{ }^{1} \text { Total VFA absorption was estimated as the fractional rate of n-valeric acid clearance }- \text { the fractional rate of } \\
\text { Co-EDTA clearance (Allen et al., 2000; Resende Júnior et al., 2006). }\end{array}$} \\
\hline \multicolumn{5}{|c|}{$\begin{array}{l}{ }^{2} \text { Total VFA passage was assumed to be equal to the fractional clearance rate of Co-EDTA (Allen et al., 2000; } \\
\text { Resende Júnior et al., 2006). }\end{array}$} \\
\hline \multicolumn{5}{|c|}{${ }^{3}$ VFA concentration $(\mathrm{mol}) \times$ rumen liquid volume $(\mathrm{kg}) \times$ fractional rate of VFA absorption $(\% / \mathrm{h})$} \\
\hline \multicolumn{5}{|c|}{$\begin{array}{l}{ }^{4} \text { Estimated according to Resende Júnior et al. (2006) where the fractional rate of acetate absorption }=5.19 \times \\
\text { fractional rate of n-valeric acid }+0.7427 \text {. }\end{array}$} \\
\hline \multicolumn{5}{|c|}{$\begin{array}{l}{ }^{5} \text { Estimated according to Resende Júnior et al. }(2006) \text { where the fractional rate of propionate absorption }=19.2 \\
\times \text { fractional rate of } \mathrm{n} \text {-valeric acid }+0.4073 \text {. }\end{array}$} \\
\hline \multicolumn{5}{|c|}{$\begin{array}{l}{ }^{6} \text { Estimated according to Resende Júnior et al. (2006) where the fractional rate of butyrate absorption }=7.21 \\
\times \text { fractional rate of n-valeric acid }+0.7000 \text {. }\end{array}$} \\
\hline${ }^{7} \mathrm{VFA}$ concentration $(\mathrm{mol}) \times \mathrm{rum}$ & & & & \\
\hline
\end{tabular}

signs were noted. The results reported in this study for increased total VFA concentration, decreased molar proportion of acetate, and decreased ruminal $\mathrm{pH}$ in response to feeding the $\mathrm{HC}$ treatment are in agreement with previous studies that used diets with differing forage to concentrate ratios (Harmon et al., 1991; McLeod and Baldwin, 2000).

We observed marked differences in the ruminal fermentation measurements including VFA profiles and ruminal $\mathrm{pH}$, but we did not detect differences in the fractional $(\% / \mathrm{h})$ or the estimated rate of absorption for total VFA $(\mathrm{mol} / \mathrm{h})$ or acetate $(\mathrm{mol} / \mathrm{h})$ and their passage from the rumen between cows fed HC and LC diets. However, when the absorption rates of individual VFA were estimated according to the calculation described by Resende Júnior et al. (2006), we found that the rates of propionate and butyrate absorption $(\mathrm{mol} / \mathrm{h})$ were higher for cows fed HC compared with LC. This was primarily caused by the greater ruminal pool sizes of propionate and butyrate for $\mathrm{HC}$ cows compared with LC cows as the fractional rate of VFA absorption was not affected by treatment. Although the estimated absorption rates of propionate and butyrate $(\mathrm{mol} / \mathrm{h})$ were greater for cows fed HC compared with those fed LC, we did not observe differences in the mRNA transcript abundance for the majority of genes investigated nor did we detect correlations between the fold change in gene expression and the estimated absorption rate for propionate or butyrate. As such, the current study does not support the idea that differences observed in the estimated rate of propionate and butyrate absorption are caused by, nor result in, greater absorptive metabolism of propionate and butyrate.

We had hypothesized that the fractional rate of VFA absorption would be greater for cows fed $\mathrm{HC}$ compared with LC, because previous studies have consistently demonstrated that lower ruminal $\mathrm{pH}$ and feeding high grain diets increase the rate of VFA absorption. For example, Dijkstra et al. (1993) used the washed reticulorumen technique to measure the fractional rate of VFA absorption as influenced by ruminal infusates with different $\mathrm{pH}$ values. They reported that as the $\mathrm{pH}$ of the infusate decreased from 7.2 to 4.5, the disappearance rate of propionate and butyrate increased, but that of

Table 5. The effect of feeding low (LC) or high concentrate (HC) diets on plasma glucose, insulin, BHBA, and urea N

\begin{tabular}{|c|c|c|c|c|}
\hline \multirow[b]{2}{*}{ Variable } & \multicolumn{2}{|c|}{ Treatment } & \multirow[b]{2}{*}{ SEM } & \multirow[b]{2}{*}{$P$-value } \\
\hline & $\mathrm{LC}$ & $\mathrm{HC}$ & & \\
\hline Glucose, mg/dL & 64.2 & 66.4 & 1.78 & 0.40 \\
\hline Insulin, $\mu \mathrm{IU} / \mathrm{mL}$ & 9.5 & 28.5 & 4.6 & 0.02 \\
\hline $\mathrm{BHBA}, \mathrm{mg} / \mathrm{dL}$ & 12.2 & 13.5 & 0.4 & 0.05 \\
\hline Urea $\mathrm{N}, \mu \mathrm{g} / \mathrm{mL}$ & 14.1 & 13.9 & 1.2 & 0.93 \\
\hline
\end{tabular}


Table 6. Fold change (FC) in the expression of genes encoding for enzymes and transporters involved in the absorption and metabolism of VFA in rumen tissues for cows fed high concentrate $(\mathrm{HC})$ or low concentrate $(\mathrm{LC})^{1}$

\begin{tabular}{|c|c|c|c|c|c|}
\hline \multirow[b]{2}{*}{ Gene (abbreviation) } & \multirow[b]{2}{*}{ Functional pathway } & \multicolumn{2}{|c|}{ Relative FC } & \multirow[b]{2}{*}{ SEM } & \multirow[b]{2}{*}{$P$-value } \\
\hline & & $\mathrm{LC}$ & $\mathrm{HC}$ & & \\
\hline Acetyl-CoA synthetase 2 (acetyl-CoA synthetase) & VFA metabolism & 1.38 & 1.47 & 0.41 & 0.88 \\
\hline Acyl-CoA synthetase short-chain family member 1 (acyl-CoA synthetase) & VFA metabolism & 2.65 & 4.05 & 0.73 & 0.21 \\
\hline Acyl-CoA synthetase medium-chain family member 1 (butyrl-CoA synthetase) & VFA metabolism & 5.42 & 3.06 & 2.49 & 0.52 \\
\hline Solute carrier family 25 , carnitine/acylcarnitine translocase, member 20 (acyl-carnitine) & VFA transport & 0.87 & 0.87 & 0.09 & 0.99 \\
\hline Acetyl-CoA acyltransferase 1 (acetyl-CoA acyltransferase) & VFA metabolism & 2.89 & 1.99 & 1.12 & 0.59 \\
\hline 3-Hydroxy-3-methylglutaryl-CoA synthase 1 (HMGS) & VFA metabolism & 1.29 & 0.94 & 0.25 & 0.35 \\
\hline 3-Hydroxymethyl-3-methylglutaryl-CoA lyase, hydroxymethylglutaricaciduria (HMGL) & VFA metabolism & 1.42 & 1.33 & 0.27 & 0.80 \\
\hline 3-Hydroxybutyrate dehydrogenase, type 1 (BDH1) & VFA metabolism & 2.48 & 2.05 & 0.33 & 0.38 \\
\hline 3-Hydroxybutyrate dehydrogenase, type 2 (BDH2) & VFA metabolism & 0.89 & 1.10 & 0.13 & 0.27 \\
\hline Propionyl Coenzyme A carboxylase, $\alpha$ polypeptide (Propionyl-CoA carboxylase) & VFA metabolism & 1.49 & 1.46 & 0.18 & 0.90 \\
\hline Lactate dehydrogenase isoform A (LDHa) & Pyruvate metabolism & 0.96 & 0.99 & 0.06 & 0.75 \\
\hline Lactate dehydrogenase isoform B ( LDHb) & Pyruvate metabolism & 1.55 & 1.47 & 0.37 & 0.88 \\
\hline Pyruvate carboxylase (PC) & Pyruvate metabolism & 1.38 & 3.48 & 1.85 & 0.45 \\
\hline Pyruvate dehydrogenase, lipoamide, $\alpha 1$ (PDHA1) & Pyruvate metabolism & 0.76 & 0.53 & 0.08 & 0.06 \\
\hline Isocitrate dehydrogenase $1, \mathrm{NADP}+$, soluble (IDH) & Tricarboxylic acid cycle & 1.05 & 0.79 & 0.13 & 0.19 \\
\hline Oxoglutarate, $\alpha$-ketoglutarate dehydrogenase, lipoamide ( $\alpha$-ketoglutarate dehydrogenase) & Tricarboxylic acid cycle & 1.03 & 0.95 & 0.22 & 0.80 \\
\hline $\begin{array}{l}\text { Solute carrier family } 25 \text {, mitochondrial carrier; adenine nucleotide translocator, } \\
\text { member } 4 \text { (ADP/ATP translocator } 4 \text { ) }\end{array}$ & Oxidative phosphorylation & 0.75 & 0.85 & 0.13 & 0.61 \\
\hline $\begin{array}{l}\text { Solute carrier family } 25 \text {, mitochondrial carrier; adenine nucleotide translocator, } \\
\text { member } 5 \text { (ADP/ATP translocator } 5)\end{array}$ & Oxidative phosphorylation & 0.67 & 0.66 & 0.22 & 0.97 \\
\hline Solute carrier family 16 , member 3 , monocarboxylic acid transporter 4 , (MCT4) & VFA transport & 1.42 & 1.34 & 0.20 & 0.78 \\
\hline ATPase, $\mathrm{Na}^{+} / \mathrm{K}^{+}$transporting, \& 1 polypeptide (Na/K ATPase) & VFA transport & 1.41 & 1.16 & 0.42 & 0.69 \\
\hline $\begin{array}{l}\text { Solute carrier family } 9 \text { sodium/hydrogen exchanger, member } 1 \\
\text { antiporter, } \mathrm{Na}^{+} / \mathrm{H}^{+}, \text {amiloride sensitive }(\mathrm{Na} / \mathrm{H} \text { antiporter) }\end{array}$ & VFA transport & 1.57 & 1.11 & 0.36 & 0.40 \\
\hline
\end{tabular}

D. Data are presented as fold change relative to the cow with the lowest acidosis index (DMI $\div$ area of $\mathrm{pH}<5.8, \mathrm{pH} \times \mathrm{min})$. 

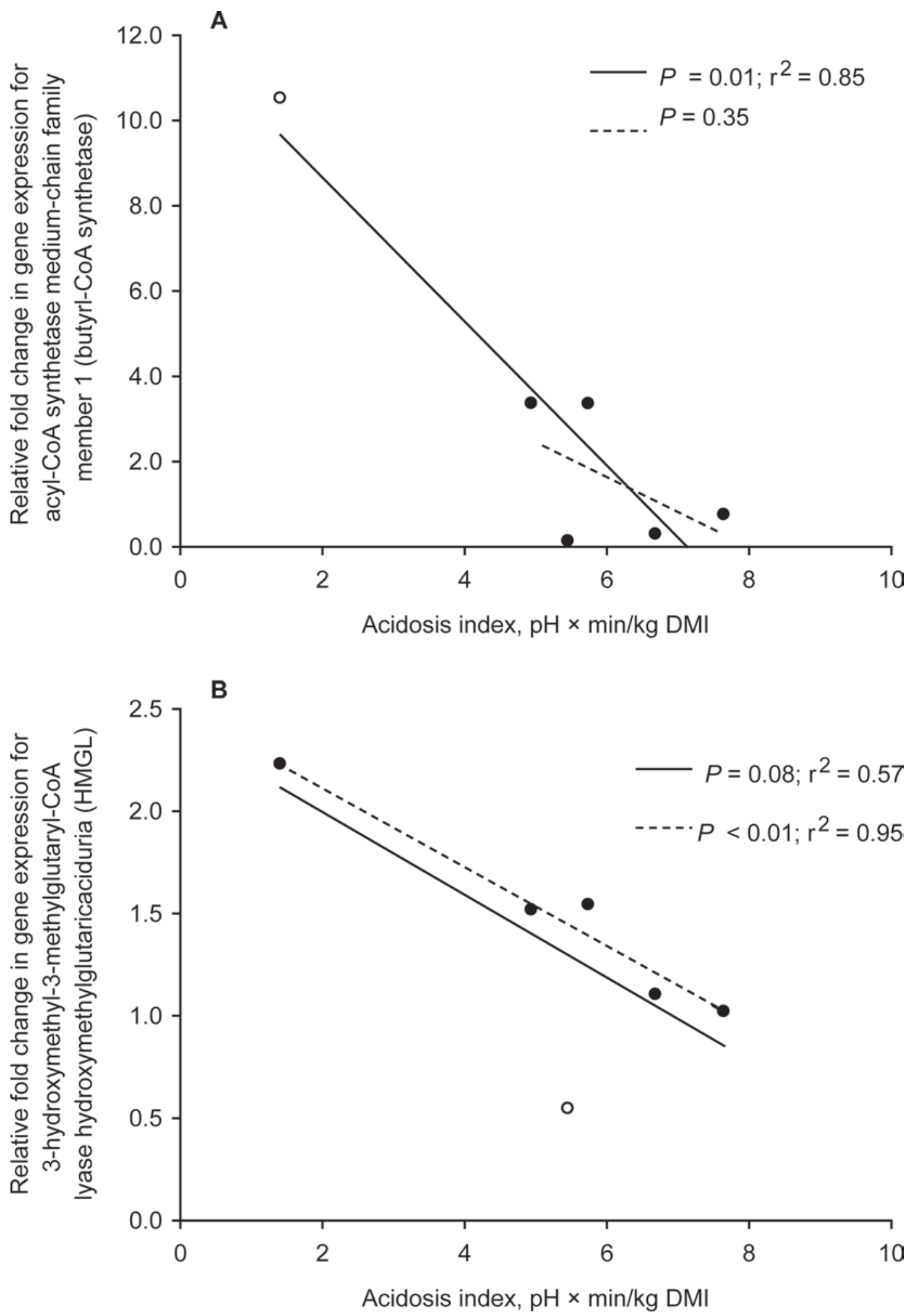

Figure 1. The relationship between the acidosis index and the relative fold change in gene expression for (A) acyl-CoA synthetase mediumchain family member 1 (butyrl-CoA synthetase) all data pairs, $P=0.01, \mathrm{r}^{2}=0.85$; without outlier, $P=0.35$, and (B) 3-hydroxymethyl-3methylglutaryl-CoA lyase hydroxymethylglutaricaciduria (HMGL) all data pairs, $P=0.08, \mathrm{r}^{2}=0.57$; without outlier, $P<0.01, \mathrm{r}^{2}=0.95$. The solid line indicates the regression including all data points and the dashed line indicates the regression with the outlier removed. Solid circles $(\bullet)$ indicate data points used in both regression lines and the open circle $(\bigcirc)$ indicates the outlier. Outliers were assessed using a DFFITS coefficient of 1.26 . 
A
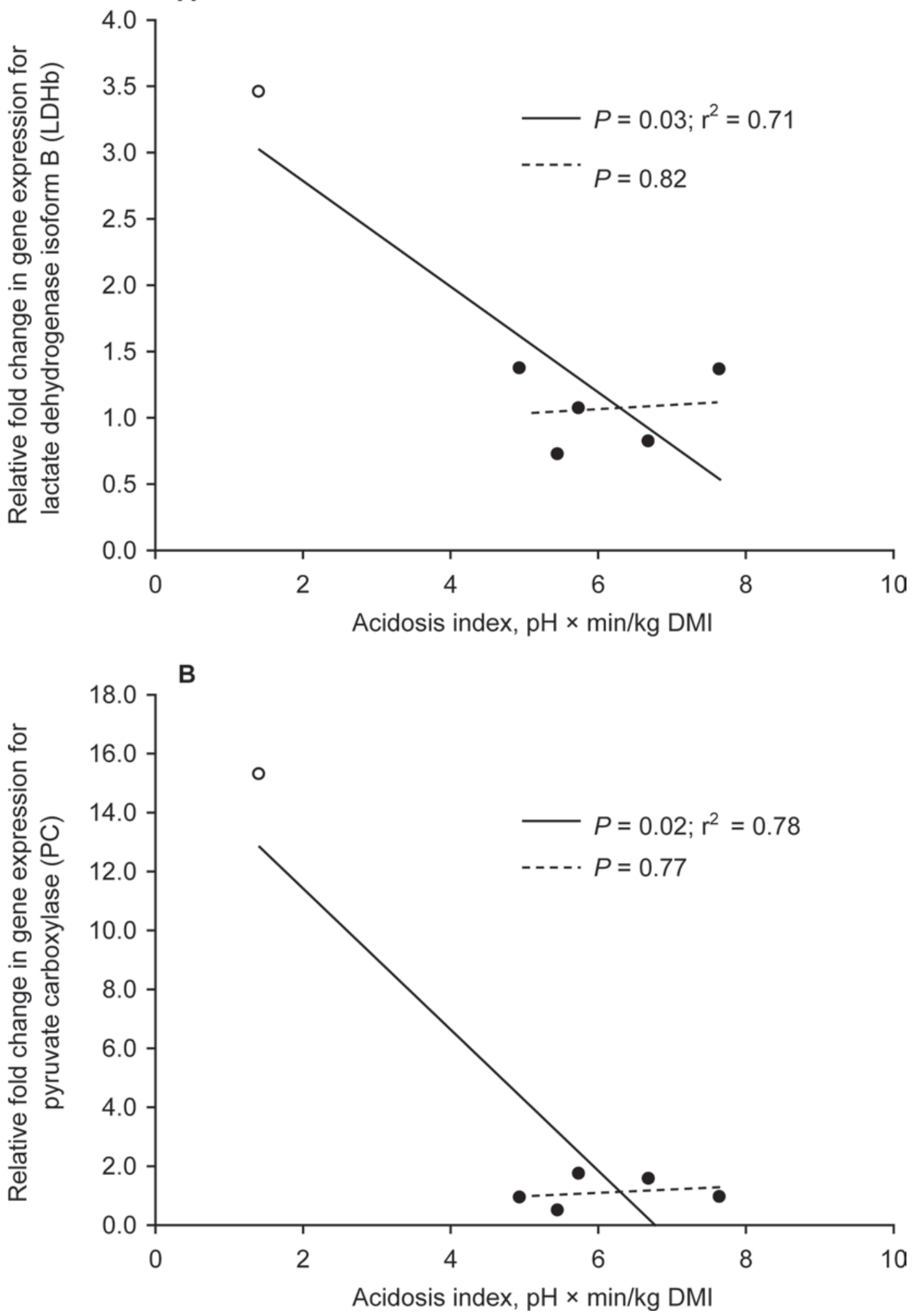

Figure 2. The relationship between the acidosis index and the relative fold change in gene expression for (A) lactate dehydrogenase isoform $\mathrm{B}(\mathrm{LDHb})$ all data pairs, $P=0.03, \mathrm{r}^{2}=0.71$; without outlier, $P=0.82$, and $(\mathrm{B})$ pyruvate carboxylase $(\mathrm{PC})$ all data pairs, $P=0.02, \mathrm{r}^{2}=0.78$; without outlier, $P=0.77$. The solid line indicates the regression including all data points and the dashed line indicates the regression with the outlier removed. Solid circles $(\bullet)$ indicate data points used in both regression lines and the open circle $(\bigcirc)$ indicates the outlier. Outliers were assessed using a DFFITS coefficient of 1.26. 
acetate was not affected. Furthermore, Sehested et al. (2000) reported increases in the net flux rate of butyrate $\left(\mu \mathrm{mol} / \mathrm{cm}^{2}\right.$ per $\left.\mathrm{h}\right)$ across ruminal epithelia for cows fed grain once daily compared with those not fed grain.

There are several possible explanations for our observation that the overall fractional rate of VFA absorption did not differ between cows fed the $\mathrm{HC}$ and $\mathrm{LC}$ treatments. First, it may be possible that diets and ruminal fermentation do not affect fractional rate of VFA absorption for nonlactating, nonpregnant cows that have low energy demand. Supporting this theory, Seal et al. (1992) reported that the rate of VFA absorption, as detected in the portal vein, was not different for steers fed an all-forage pellet or a diet containing $50 \%$ of the forage pellet and $50 \%$ flaked maize. Other studies examining VFA absorption have been conducted in vitro and have measured VFA absorption per area of epithelia exposed (Sehested et al., 2000) or have measured the fractional rate of VFA disappearance under artificial conditions in vivo (washed reticulo-rumen technique; Dijkstra et al., 1993), and therefore should be interpreted with caution. With the washed reticulorumen technique, for example, the ratio of the ruminal content volume to ruminal surface area is lower than that under physiological conditions. Decreasing the ratio of ruminal content volume to ruminal surface area would likely increase the efficiency of ruminal contractions to mix ruminal contents, thereby exposing more substrate to the ruminal epithelia, and possibly over-estimating the fractional rate of VFA absorption. Supporting this speculation, Dijkstra et al. (1993) reported a $25 \%$ decrease in the fractional rate of butyrate disappearance from the rumen when ruminal content volume increased by $20 \mathrm{~L}$.

The second possibility is that the treatments imposed in this study did not elicit large changes in the absorptive surface area of the ruminal epithelia, and consequently did not affect the fractional rate of absorption. Dirksen et al. (1985) suggested that maximum papillae growth is achieved after 6 to $8 \mathrm{wk}$ of feeding a more fermentable diet, but Penner et al. (2006b) suggested that less time is required under conventional feeding systems in North America where higher energy diets are fed. Further, the assumption that papillae surface area limits absorption has been questioned based on in vitro studies (Andersen et al., 1999; Sehested et al., 2000).

A third possibility is that the low ruminal $\mathrm{pH}$ observed for the HC treatment may have caused additional keratinization of the ruminal epithelia, thereby decreasing the fractional absorption rate. We did not conduct measurements on ruminal papillae gross morphology or histology in this study, and therefore are unable to speculate whether changes in surface area or keratinization affected our results for VFA absorption.

Finally, it is also possible that the model used to measure the fractional rate of VFA absorption is not sensitive enough to detect differences. The lack of sensitivity may be due to inherent limitations of the method. For example, in the current study, following the ruminal dose of the marker, we observed large increases in ruminal osmolarity from a baseline of $323 \mathrm{mOsm}$ before dosing to a peak osmolarity of $357 \mathrm{mOsm}$ at 30 min after the dose (data not shown). The temporal increase in osmolarity may have decreased the absorption rate (Owens et al., 1998) for both treatments, masking treatment effects. Furthermore, the Co-EDTA/n-valeric acid method relies on 3 assumptions: 1) n-valeric acid is not metabolized extensively by the ruminal microflora, 2) the rate of passage from the rumen is equal for Co-EDTA and n-valeric acid, and 3) the rate of n-valeric acid absorption is similar to the rates of absorption for other VFA (Allen et al., 2000). The last assumption likely causes a decrease in accuracy for this method because of the interactions between VFA chain length and ruminal $\mathrm{pH}$ for the fractional rate of absorption (Dijkstra et al., 1993; Sehested et al., 1999). More recently, Resende Júnior et al. (2006) compared absorption rates using ${ }^{13} \mathrm{C}$-labeled VFA and the absorption rates obtained using the Co-EDTA/n-valeric acid method. Their results demonstrated that VFA chain length did not affect in vivo clearance rates and that the Co-EDTA/n-valeric acid method produced similar results to the stable isotope method; however, they did not account for the intraruminal conversion of ${ }^{13} \mathrm{C}$ among VFA as demonstrated by Sutton et al. (2003), which may have affected their results. Future research should be directed toward an improved understanding of factors affecting the absorption of VFA across the rumen under physiological conditions.

\section{Ketogenesis}

Harmon et al. (1991) fed diets containing 90\% forage or $90 \%$ grain, and found that the activity of butyrlCoA synthetase was increased for cows fed $90 \%$ grain but no differences were observed for the activities of acetyl-CoA synthetase and propionyl-CoA synthetase. In the current study, we evaluated the gene expression of acyl-CoA synthetase, acetyl-CoA synthetase, and butyrl-CoA synthetase but did not detect any differences between treatments. It must be acknowledged that changes in gene expression do not necessarily indicate differences in protein abundance or activity caused by post-translational regulation. Furthermore, the relationship between butyrate activation and butyrate ab- 
sorption is questionable as Harmon et al. (1991) found increases in the activity of butyrl-CoA synthetase, but no differences in the mucosal uptake of butyrate per milligram of tissue.

Extensive metabolism of butyrate occurs across the ruminal epithelia. Sehested et al. (1999) reported that approximately $95 \%$ of the butyrate absorbed from the isolated bovine mucosa was metabolized, and that $94 \%$ of the metabolized butyrate was converted to non$\mathrm{CO}_{2}$ metabolites. As such, we hypothesized that gene expression for enzymes involved in ketogenesis would increase when cows were fed the HC diet. Genes evaluated included acetyl-CoA acyltransferase, which is the enzyme catalyzing the first reaction where 2 acetyl-CoA molecules are converted into one acetoacetyl-CoA molecule. We also investigated the relative abundance of mRNA transcripts for HMGS, HMGL, and 2 isoforms of BDH. Gene expression between $\mathrm{HC}$ and LC treatments was not different for ketogenic enzymes, which was unexpected because cows fed the $\mathrm{HC}$ treatment had higher plasma concentrations of BHBA. Because the cows were nonlactating and fed diets to meet their ME requirements, BHBA was not likely produced from incomplete oxidation of fatty acids in the liver, but rather from ketogenesis in the ruminal epithelia. This is consistent with higher butyrate concentration in ruminal fluid for $\mathrm{HC}$ cows compared with LC cows. Although the expected ruminal butyrate supply and plasma BHBA concentration were greater for cows fed $\mathrm{HC}$, no differences were observed for the expression of genes encoding for ketogenic enzymes in the current study. Harmon et al. (1991) reported no differences in the net production of acetoacetate and BHBA from acetate and butyrate by ruminal papillae slices collected from cattle fed a $90 \%$ concentrate or $90 \%$ forage diet; however, increased oxidation of both acetate and butyrate was detected in papillae slices when cattle were fed $90 \%$ concentrate compared with $90 \%$ forage. These data lead to the speculation that the dietary forage to concentrate ratio may affect the partitioning of acetate and butyrate metabolism in ruminal tissue.

\section{Pyruvate Metabolism}

Pyruvate is a central intermediate for energy metabolism, and partitioning of pyruvate metabolism can greatly affect energy supply to the cell. No previous studies known by the authors have investigated the expression of genes related to pyruvate metabolism in bovine ruminal tissue. We found that cows fed $\mathrm{HC}$ had decreased expression of PDHA1, the enzyme that catalyzes the conversion of pyruvate to acetyl-CoA. In ruminal tissue, pyruvate can be produced via glycolysis or via oxaloacetate as catalyzed by phosphoenolpyruvate carboxykinase. However, if feeding $\mathrm{HC}$ increased the oxidation of butyrate and acetate as discussed previously, the reliance on PDHA1 to supply acetyl-CoA may be decreased. Although cows fed HC and LC had similar fractional rates of VFA absorption, increases in the acetyl-CoA pool size could be expected in the current study as cows fed HC had higher VFA concentration in the rumen. Therefore, as the estimated rate of butyrate absorption $(\mathrm{mol} / \mathrm{h})$ was higher for cows fed HC than LC, increased butyrate supply could lead to a greater acetyl-CoA pool size caused by metabolism of butyrate. Propionate supply from the rumen is also expected to be greater for cows fed $\mathrm{HC}$ compared with those fed LC, but we are unable to speculate on the contribution of propionate to the pyruvate pool through phosphoenolpyruvate carboxykinase. Although we used 3 different primer sequences for phosphoenolpyruvate carboxykinase, the tested sequences were not successful in producing a single amplicon or producing an amplicon in sufficient quality. Future studies should utilize stable isotopes to investigate the partitioning of VFA metabolism in ruminal tissue for cows fed various dietary regimens and to determine if the expression of genes coding for regulating enzymes correlates with the production of their intermediates.

\section{Observed Variation}

In the present study, considerable variation existed in the response of cows fed the $\mathrm{HC}$ diet. Although all 6 cows on the HC treatment were fed a common diet, one cow had markedly higher mean $\mathrm{pH}$ (6.19) and a lower acidosis index (6.4) than the other cows. Other studies have also noted large variation in ruminal $\mathrm{pH}$, and the severity of acidosis within a treatment. For example, Brown et al. (2000) challenged 5 steers by ruminally dosing steam-flaked corn at $3 \%$ of BW after $1 \mathrm{~d}$ of feed restriction. The response to the challenge in that study ranged from euthanization because of acute ruminal acidosis to undetectable ruminal acidosis in another steer. Bevans et al. (2005) subjected beef heifers to a rapid adaptation ( $40 \%$ concentrate diet to a $90 \%$ concentrate diet in $4 \mathrm{~d}$ with one intermediate diet) or gradual adaptation protocol (40\% concentrate diet to a $90 \%$ concentrate diet over $16 \mathrm{~d}$ with 5 intermediate diets). Bevans et al. (2005) showed that some heifers on both treatments were able to tolerate their adaptation protocol with minimal disruption to fermentation (normal diurnal variation in ruminal $\mathrm{pH}$ and maintenance of DMI), whereas others responded poorly (extended periods of low ruminal $\mathrm{pH}$ and variation in DMI). They also noted that some cows were able to tolerate low 
ruminal $\mathrm{pH}$ without noticeable decreases in animal performance. However, we are not aware of any studies investigating the causes for the variation.

Negative relationships were observed between the acidosis index and the expression level of butyrl-CoA synthetase, $\mathrm{PC}$, and $\mathrm{LDHb}$ genes, and a tendency for a negative relationship between the acidosis index and HMGL. These observations indicate that cows experiencing less severe ruminal acidosis had greater gene expression. Sensitivity analysis (DFFITS) of the regressions revealed that one cow was an outlier; upon removal of that cow, no relationships were observed. The exception was the negative relationship between the acidosis index and HMGL, which was improved with the removal of the outlier. However, in this case the outlier was a different cow than for the other variables. These data are collectively interpreted to suggest that as cows experienced more severe ruminal acidosis (increased acidosis index), the expression of genes related to VFA metabolism were decreased. It must be noted that this regression approach does not imply a cause-and-effect relationship, and the data should be interpreted with caution as only 6 animals were used to derive the relationships. Further research is warranted to determine the relationship between ruminal VFA absorption and metabolism and the severity of ruminal acidosis.

We expected that differences in the gene expression for enzymes and transport proteins related to the absorption and metabolism of VFA would be positively associated with the estimated rates of VFA absorption $(\mathrm{mol} / \mathrm{h})$. However, we did not detect these relationships in the current study. The VFA absorption via passive diffusion is thought to be mediated by concentration gradients between the ruminal contents, the cytosol, and portal circulation, and by the lipophilic nature of individual VFA (Dijkstra, 1994; Rémond et al., 1996). As such, it is unclear why cows fed HC did not have an increased fractional rate of VFA absorption as ruminal $\mathrm{pH}$ was lower; the concentration of undissociated VFA in ruminal fluid should be greater for cows fed HC than LC. Alternatively, it is possible that the metabolism of VFA has a regulatory role in VFA absorption. For example, metabolism would help maintain a concentration gradient between the ruminal contents and the cytosol and increased VFA metabolism should thereby increase VFA absorption. However, our data do not support this speculation but the lack of relationships may be due, at least in part, to limited sensitivity of the Co-EDTA/n-valeric acid method to determine VFA absorption as described previously.

\section{CONCLUSIONS}

Feeding a diet containing a greater proportion of concentrate decreased ruminal $\mathrm{pH}$ and increased VFA concentration. However, the fractional rate of VFA absorption in vivo was not affected, indicating the need for further investigation into factors affecting the absorption of VFA in vivo. Further, we found negative correlations between the severity of ruminal acidosis, as indicated by the acidosis index, and the expression of genes related to VFA activation, ketogenesis, and pyruvate metabolism. A greater understanding of mechanisms involved in VFA absorption and metabolism will increase our knowledge of energy metabolism by ruminal tissue, and may lead to the development of strategies to decrease the occurrence and severity of ruminal acidosis.

\section{ACKNOWLEDGMENTS}

The authors of this study gratefully acknowledge technical assistance from K. Andrews, B. Farr, L. Holthausen, D. Baines, R. Wuerful, K. Koenig, W. Yang, and A. Furtado at the Lethbridge Research Centre. In addition, C. Owen and A. Ruiz-Sanchez are acknowledged for their skilled technical assistance at the University of Alberta. We thank W. Dixon (University of Alberta) for use of the 7900HT Fast Real-Time PCR System and the Dairy and Metabolism Unit Staff at the Lethbridge Research Centre for general husbandry duties. Financial support of G. Penner was provided through the National Science and Engineering Research Council. Agriculture and Agri-Food Canada provided financial support for the animal experimentation.

\section{REFERENCES}

Allen, M. S. 1997. Relationship between fermentation acid production in the rumen and the requirement for physically effective fiber. J. Dairy Sci. 80:1447-1462.

Allen, M. S., L. E. Armentano, M. N. Pereira, Y. Ying, and J. Xu. 2000. Method to measure fractional rate of volatile fatty acid absorption from the rumen. Page 26 in Proc. 25th Conf. Rumen Function, Chicago, IL.

Andersen, J. B., J. Sehested, and K. L. Ingvartsen. 1999. Effect of dry cow feeding strategy on rumen $\mathrm{pH}$, concentration of volatile fatty acids and rumen epithelium development. Acta Agric. Scand. A. 49:149-155.

AOAC. 1990. Official Methods of Analysis. Vol. I. 15th ed. Association of Official Analytical Chemists, Arlington, VA.

Bevans, D. W., K. A. Beauchemin, K. S. Schwartzkopf-Genswein, J. J. McKinnon, and T. A. McAllister. 2005. Effect of rapid or gradual grain adaptation on subacute acidosis and feed intake by feedlot cattle. J. Anim. Sci. 83:1116-1132.

Brown, M. S., C. R. Krehbiel, M. L. Galyean, M. D. Remmenga, J. P. Peters, B. Hibbard, J. Robinson, and W. M. Moseley. 2000. 
Evaluation of models of acute and subacute acidosis on dry matter intake, ruminal fermentation, blood chemistry, and endocrine profiles of beef steers. J. Anim. Sci. 78:3155-3168.

Chomczynski, P., and N. Sacchi. 1987. Single-step method of RNA isolation by acid guanidinium thiocyanate-phenol-chloroform extraction. Anal. Biochem. 162:156-159.

Dijkstra, J. 1994. Production and absorption of volatile fatty acids in the rumen. Livest. Prod. Sci. 39:61-69.

Dijkstra, J., H. Boer, J. V. Bruchem, M. Bruining, and S. Tamminga. 1993. Absorption of volatile fatty acids from the rumen of lactating dairy cows as influenced by volatile fatty acid concentration, $\mathrm{pH}$ and rumen liquid volume. Br. J. Nutr. 69:385-396.

Dirksen, G. U., H.-G. Liebich, and E. Mayer. 1985. Adaptive changes of the ruminal mucosa and their functional and clinical significance. Bov. Pract. 20:116-120.

Enemark, J. M. D. 2008. The monitoring, prevention and treatment of sub-acute ruminal acidosis (SARA): A review. Vet. J. 176:3243.

Fawcett, J. K., and J. E. Scott. 1960. A rapid and precise method for the determination of urea. J. Clin. Pathol. 13:156-160.

Gäbel, G., and J. R. Aschenbach. 2006: Ruminal SCFA absorption: Channeling acids without harm. Pages 173-195 in Ruminant Physiology: Digestion, Metabolism and Impact of Nutrition on Gene Expression, Immunology and Stress. K. Sejrsen, T. Hvelplund, and M. O. Nielsen, ed. Wageningen Academic Publishers, Wageningen, the Netherlands.

Gäbel, G., M. Bestmann, and H. Martens. 1991. Influences of diet, short-chain fatty acids, lactate and chloride on bicarbonate movement across the reticulo-rumen wall of sheep. Zentralbl. Veterinarmed. A 38:523-529.

Harmon, D. L., K. L. Gross, C. R. Krehbiel, K. K. Kreikemeier, M. L. Bauer, and R. A. Britton. 1991. Influence of dietary forage and energy intake on metabolism and acyl-CoA synthetase activity in bovine ruminal epithelial tissue. J. Anim. Sci. 69:4117-4127.

Krause, M. K., and G. R. Oetzel. 2006. Understanding and preventing subacute ruminal acidosis in dairy herds: A review. Anim. Feed Sci. Technol. 126:215-236.

Livak, K. J., and T. D. Schmittgen. 2001. Analysis of relative gene expression data using real-time quantitative PCR and the $2^{-\Delta \Delta C} \mathrm{~T}$ method. Methods 25:402-408.

McLeod, K. R., and R. L. Baldwin. 2000. Effect of diet forage:concentrate ratio and metabolizable energy intake on visceral organ growth and in vitro oxidative capacity of gut tissues in sheep. J. Anim. Sci. 78:760-770.

Nagaraja, T. G., and E. C. Titgemeyer. 2007. Ruminal acidosis in beef cattle: The current microbiological and nutritional outlook. J. Dairy Sci. 90(E. Suppl.):E17-E38.

Ontsouka, E. C., B. Korczak, H. M. Harmon, and J. W. Blum. 2004. Real-time PCR quantification of bovine lactase mRNA localizationin the gastrointestinal tract of milk-fed calves. J. Dairy Sci. 87:4230-4237.

Owens, F. N., D. S. Secrist, W. J. Hill, and D. R. Gill. 1998. Acidosis in cattle: A review. J. Anim. Sci. 76:275-286.
Penner, G. B., K. A. Beauchemin, and T. Mutsvangwa. 2006a. An evaluation of the accuracy and precision of a stand-alone submersible continuous ruminal $\mathrm{pH}$ measurement system. J. Dairy Sci. 89:2132-2140.

Penner, G. B., K. A. Beauchemin, and T. Mutsvangwa. 2007. Severity of ruminal acidosis in primiparous Holstein cows during the periparturient period. J. Dairy Sci. 90:365-375.

Penner, G. B., K. A. Beauchemin, T. Mutsvangwa, and A. G. Van Kessel. 2006b. Adaptation of ruminal papillae in transition dairy cows as affected by diet. Can. J. Anim. Sci. 86:578. (Abstr.)

Rémond, D., F. Meschy, and R. Bovin. 1996. Metabolites, water and mineral exchanges across the rumen wall: Mechanisms and regulations. Ann. Zootech. 45:97-119.

Resende Júnior, J. C., M. N. Pereira, H. Boer, and S. Tamminga. 2006. Comparison of techniques to determine the clearance of ruminal volatile fatty acids. J. Dairy Sci. 89:3096-3106.

Rhee, K. C. 2005. Determination of total nitrogen. Pages 105-113 in Handbook of Food Analytical Chemistry: Water, Proteins, Enzymes, Lipids, and Carbohydrates. R. E. Wrolstad, E. A. Decker, S. J. Schwartz, and P. Sporns, ed. John Wiley and Sons, Hoboken, NJ.

Seal, C. J., D. S. Parker, and P. J. Avery. 1992. The effect of forage and forage-concentrate diets on rumen fermentation and metabolism of nutrients by the mesenteric- and portal-drained viscera in growing steers. Br. J. Nutr. 67:355-370.

Sehested, J., J. B. Andersen, O. Aaes, N. B. Kristensen, L. Diernaes, P. D. Møller, and E. Skadhauge. 2000. Feed induced changes in the transport of butyrate, sodium and chloride ions across the isolated bovine rumen epithelium. Acta Agric. Scand. A 50:47-55.

Sehested, J., L. Diernaes, P. D. Møller, and E. Skadhauge. 1999. Ruminal transport and metabolism of short-chain fatty acids (SCFA) in vitro: Effect of SCFA chain length and $\mathrm{pH}$. Comp. Biochem. Physiol. A 123:359-368.

Sutton, J. D., M. S. Dhanoa, S. V. Morant, J. France, D. J. Napper, and E. Schuller. 2003. Rates of production of acetate, propionate, and butyrate in the rumen of lactating dairy cows given normal and low-roughage diets. J. Dairy Sci. 86:3620-3633.

Uden, P., P. E. Colucci, and P. J. Van Soest. 1980. Investigation of chromium, cerium and cobalt as markers in digesta. Rate of passage studies. J. Sci. Food Agric. 31:625-632.

Uppal, S. K., K. Wolf, S. S. Khahra, and H. Martens. 2003. Modulation of $\mathrm{Na}^{+}$transport across isolated rumen epithelium by short-chain fatty acids in hay- and concentrate-fed sheep. J. Anim. Physiol. Anim. Nutr. (Berl.) 87:380-388.

Van Soest, P. J., J. B. Robertson, and B. A. Lewis. 1991. Methods for dietary fiber, neutral detergent fiber and non-starch polysaccharide in relation to animal nutrition. J. Dairy Sci. 74:3583-3597.

Wildman, E. E., G. M. Jones, P. E. Wagner, R. L. Boman, H. F. Trout Jr., and T. N. Lesch. 1982. A dairy cow body condition scoring system and its relationship to selected production characteristics. J. Dairy Sci. 65:495-501. 